\title{
Perceived fairness of revenue management in the US golf industry
}

\author{
Sheryl E. Kimes \\ School of Hotel Administration, Cornell University \\ Jochen Wirtz
}

NUS Business School, National University of Singapore

\begin{abstract}
KEYWORDS: revenue management, demand-based pricing, perceived fairness, golf courses
\end{abstract}

Experience in other industries has shown that revenue management can increase revenue without affecting customer satisfaction. Revenue management, however, is underutilised in the golf industry, as customers are believed to perceive such practices as unacceptable and unfair. This paper explores six revenue management practices that might be suitable in a golf context and examines their perceived fairness. The results show that golfers perceive arrival duration control practices in the form of reservation fees or no-show fees as fair. In addition, it was found that golfers perceive demand-based pricing in the form of coupons (two for the price of one), time-of-day and reduced tee time intervals as fair. Conversely, time-of-booking pricing was perceived as neutral to slightly unfair. Varying price levels were seen as unfair, with potential negative consumer reactions to this practice. Furthermore, the paper explores whether framing demand-based pricing as discounts rather than surcharges would make a difference. It was found that demand-based pricing presented as discounts were generally seen as fairer and therefore less likely to have a negative impact on consumer perceptions and reactions.

\section{Introduction}

Revenue management has been widely adopted in the airline, hotel and rental car industries (Hanks et al., 1992; Smith et al., 1992; Carroll and Grimes, 1995), but has only recently gained attention in the golf industry (Kimes, 2000; Kimes and Schruben, 2002). Companies using revenue management have reported revenue increases of 2-5 per cent (Hanks et al., 1992; Smith et al., 1992), and the potential revenue gain for the golf industry can be substantial. 
Revenue management consists of two strategic levers: duration control and demand-based pricing (Kimes and Chase, 1998; Kimes, 2000). Golf courses have been willing to try managing duration (Kimes, 2000) but have been reluctant to apply demand-based pricing because of fears of possible customer dissatisfaction. While golf courses do use demand-based pricing when offering higher prices on weekends and promotions such as twilight specials and league play, they have been loathe to vary price by time of day, time of booking or condition of play.

Golf is a popular sport in the USA, with over 25 million players. In 2002, there were over 17,000 golf courses in the USA, of which nearly 13,000 were open to the public. The average greens fee was $\$ 40$ at public courses and $\$ 36$ at municipal courses, and $\$ 16.3 \mathrm{bn}$ was spent on greens fees and dues (National Golf Foundation, 2002). The focus of this research was on the customers of high-end daily greens-fee courses.

Golf course operators may well have support for their fears in the fairness literature.

Researchers have found that customers will refuse to patronise companies perceived as unfair. If demand-based pricing in golf courses is viewed as unfair by golfers, the golf course may suffer a loss of business. The intent of this research was to determine how customers react to revenue management practices in the golf industry.

\section{PROBLEM BACKGROUND}

\section{Revenue management}

Revenue management is the application of information systems and pricing strategies to allocate the right capacity to the right customer at the right place at the right time. The determination of 'right' entails achieving the most contribution possible for the golf course, while also delivering the greatest value or utility to the customer. In practice, revenue management has meant setting prices according to predicted demand levels so that price-sensitive customers who are willing to purchase at off-peak times can do so at favourable prices, while price-insensitive customers who want to purchase at peak times will be able to do so. The application of revenue management applied to operations that have a relatively fixed capacity, demand that is variable and uncertain, perishable inventory, appropriate cost and pricing structure, and varying customer price sensitivity. Those attributes are found in the golf industry. 
Golf courses possess many of the characteristics that call for revenue management, but little evidence is seen of managers using a strategic approach for deploying the demand-management mechanisms at hand. A successful revenue-management strategy is predicated on effective control of customer demand. Two strategic levers for golf course revenue management are available: duration management and demand-based pricing (Kimes and Chase, 1998).

Different industries are subject to different combinations of duration control and variable pricing (see Table 1). Industries traditionally associated with revenue management (hotels, airlines, carrental firms and cruise lines) are able to apply variable pricing for a product that has a specified or predictable duration (Quadrant 2). Movie theatres, performing-arts centres, arenas and convention centres charge a fixed price for a product of predictable duration (Quadrant 1), while golf courses, restaurants and most Internet service providers charge a fixed price but face a relatively unpredictable duration of customer use (Quadrant 3). Some healthcare services charge variable prices (eg HMOs, Medicare versus private pay), and some may try to control the duration of use (Quadrant 4). The lines dividing the quadrants are broken because in reality no fixed demarcation point exists between quadrants. Thus, an industry (such as golf) may have attributes from more than one quadrant.

Golf course operators can use round duration control and variable pricing to help maximise their revenue per available tee time. Round duration can be managed by reducing the uncertainty of arrival, by reducing the uncertainty of duration and/ or by reducing the tee time interval so that more golfers can be served. Variable pricing can be implemented by developing optimal prices and by setting rules to determine who is charged which price. These techniques have been thoroughly discussed in an earlier paper (Kimes, 2000)

\section{Fairness}

Golf courses are often reluctant to use revenue management tools because of potential customer backlash. Customers may perceive revenue management practices as unfair, and researchers have found that fair behaviour as seen by customers is instrumental to the maximisation of long-term profits (Thaler 1985; Kahneman et al., 1986a, b). 
Table 1: Strategic levers of revenue management

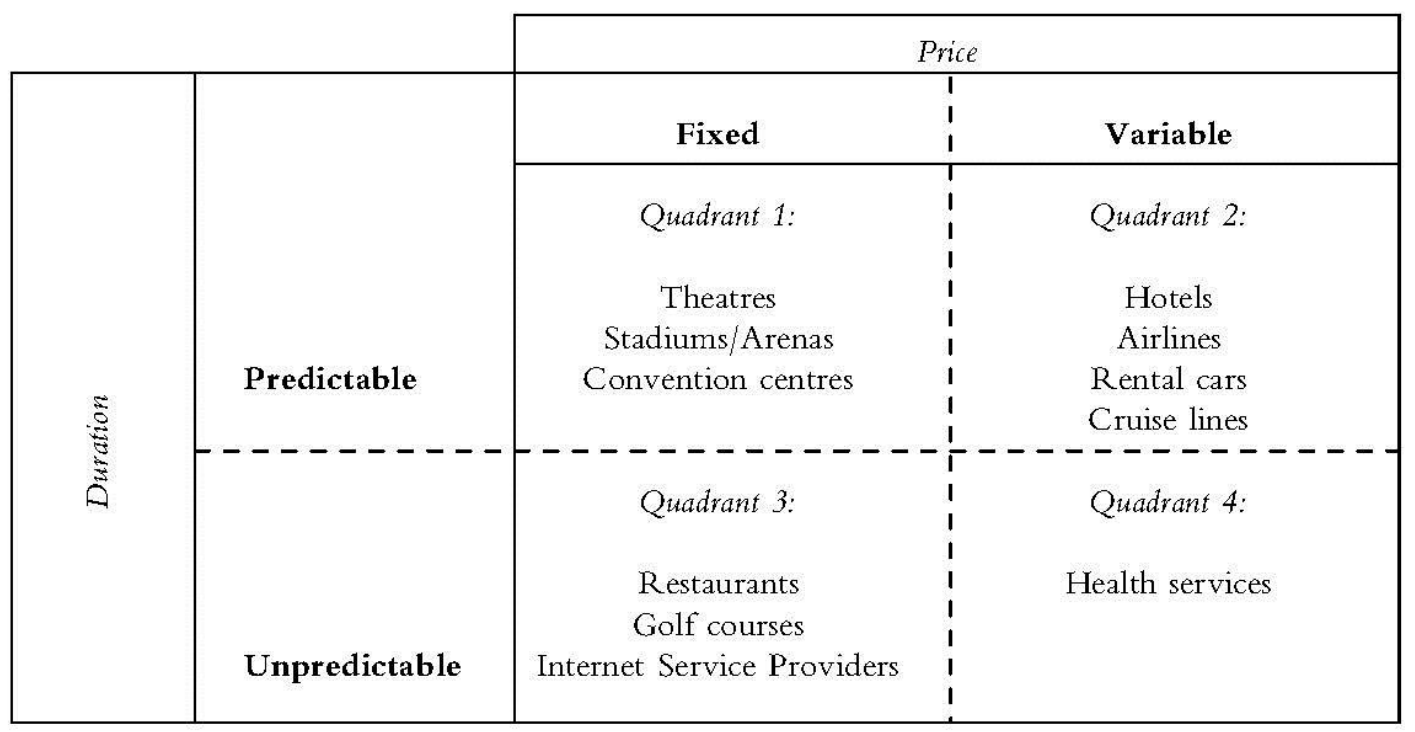

The issue of fairness has been studied extensively in the field of marketing in a variety of nonhospitality industries (Thaler, 1985; Kahneman et al., 1986a, b; Urbany et al., 1989; Kaufmann et al., 1991; Campbell, 1999a, b) and Kimes (1994) studied perceived fairness in the hotel and airline industries. In discussions on perceived fairness, the terms 'reference transaction' and 'reference price' are often used. A reference transaction is how customers think a transaction should be conducted, and a reference price is how much customers think a service should cost. Reference prices come from market prices, posted prices and past experience with the company. For example, customers may know that they generally pay about $\$ 75$ to play golf at a particular course, and so the reference price for a round of golf at that course would be $\$ 75$.

\section{Dual entitlement}

The principle of dual entitlement holds that most customers believe that they are entitled to a reasonable price and that firms are entitled to a reasonable profit (Thaler, 1985) Two hypotheses emerge from that principle:

(1) Customers feel that raising the price to maintain profits is fair. That means if costs increase, customers consider it reasonable for the price of the service to also increase. 
(2) Customers believe that raising the price to increase profits is unfair. For example, after Hurricane Andrew in the early 1990s, many companies charged significantly increased prices for food, water and supplies. As predicted by the principle of dual entitlement, consumers considered these practices extremely unfair (Campbell, 1999a).

Furthermore, customers believe that the value to the firm should equal the value to the customer (Kahneman et al., 1986a, b). If that relationship becomes unbalanced by increasing the value to the firm or decreasing the value to the customer, the customer may view subsequent transactions as unfair. For example, if a golf course increases its greens fees for no apparent reasons, it is increasing the firm's value without increasing the customer's value. The customer may then view the transaction as unfair. Similarly, if a golf course imposes substantial restrictions on customers in exchange for only a marginally lower price, customers may also view the transaction as unfair.

If the principle of dual entitlement holds true, revenue management may be perceived as unfair. If customers believe that the transaction is different from the reference transaction only in price, they may believe that the firm is receiving more than its reference price and is behaving unfairly. The experimental research of Kahneman et al. $(1986 a, b)$ indicates the willingness on the part of the subject to 'punish' unfair pricing behaviour, even at some costs to themselves.

\section{Rate fences}

Fenced prices are designed to allow customers to segment themselves based on their willingness to pay, behaviour and needs (Hanks et al., 1992). Fences offer consumers discounted prices but impose rules and regulations at every level of discount to balance the perceived value for the different market segments, and to avoid automatically offering a discount to customers who are willing to pay a higher price (Hanks et al., 1992). Types of fences include requirements for advance purchase, advance payment, cancellation and change restrictions, refund penalties, time of usage restrictions and minimum consumption quantities. For example, airlines offer many different fares, but in order to qualify for a deeply discounted fare, customers may have to make their reservation and purchase the ticket far in advance, stay over a Saturday night and accept cancellation penalties. The business traveler who is unwilling to accept the restrictions does not qualify for the lower rate and usually ends up paying a higher fare. 
The purpose of a rate fence is to segment customers and justify why different people pay different prices. In order to be perceived as fair, fences need to be logical, transparent, upfront and fixed so that they cannot be circumvented (Bennett, 1984).

Essentially, there are two types of rate fence that companies can use to customize their prices: physical and non-physical (Hanks et al., 1992). Physical rate fences include physical location, furnishings, presence of amenities or view, while nonphysical rate fences include time of consumption, transaction characteristics, buyer characteristics and controlled availability (Dolan and Simon, 1996).

Physical rate fences for golf courses might include inclusion of a cart, the use of a better course, or amenities (free lessons, hats or food and beverage). Non-physical rate fences might include time (weekend mornings might cost more or rounds played after before $2 \mathrm{pm}$ might cost less), transaction characteristics (golfers who make a reservation over a month ahead of time might pay less), buyer characteristics (frequent customers might pay less), or controlled availability (customers with coupons will pay less).

The purpose of any rate fence is to ensure that customers who are willing to pay a higher price are not arbitrarily sold the product at a lower price. When developing rate fences, golf course operators must make sure that the rate fences are easy to explain and administer and that customers can understand the reasoning behind them.

\section{Framing of price differences}

Behavioural decision theory (Kahneman and Tversky, 1979) holds that the way in which an alternative is presented (its framing) affects its evaluation. Frames that emphasise customer gains are preferable to economically equivalent frames that emphasise customer losses. In the context of revenue management, it would therefore be expected that consumers would evaluate a situation framed as a price discount more favourably than a situation presented as a price surcharge or increase. For example, consider a golf course that decides to charge a $\$ 20$ higher greens fee for rounds played before 10 am on a Saturday morning than for rounds played between $10 \mathrm{am}$ and noon on the same day. They can present the price differences in two ways: they can either present the late morning greens fees as $\$ 20$ lower than early morning prices or they can present the early morning prices as $\$ 20$ higher than late morning prices. The situations are economically equivalent, but behavioural decision theory would hold that customers would view the $\$ 20$ lower prices more favourably, and that the golf course should frame the 
price difference accordingly. This study explored the impact of framing on the perceived fairness of different rate fences.

\section{THE STUDY}

Golf courses can vary price by time of week, by time of day, by when the tee time was booked, through the use of coupons, and by the tee time interval. They can also use price to help reduce no-show rates by imposing no-show or reservation fees. Again, demand-based pricing is only successful if customers view the practices as fair. In an attempt to understand how golfers view various revenue management practices, surveys were sent to a randomly selected sample of 1,000 golfers. Troon Golf, a golf management company that manages over 100 golf courses around the world, provided names and addresses from their one-million-customer database. This study restricted the sample to US golfers who had recently played at high-end daily greens-fee courses.

Table 2: Operationalisation of experimental conditions

\begin{tabular}{|c|c|c|}
\hline $\begin{array}{l}\text { Revenue } \\
\text { management practices }\end{array}$ & Operationalisation & Frame \\
\hline $\begin{array}{l}\text { Time-of-day } \\
\text { pricing }\end{array}$ & $\begin{array}{l}\text { A } 20 \% \text { price difference between peak } \\
\text { times (before } 10 \mathrm{am} \text { ) and lower } \\
\text { demand times (from } 10 \text { am to noon) }\end{array}$ & $\begin{array}{l}\text { Discount: A } 20 \% \text { lower fee for } \\
\text { playing between } 10 \text { am to noon } \\
\text { Surcharge: A } 20 \% \text { higher fee for } \\
\text { playing before } 10 \text { am }\end{array}$ \\
\hline $\begin{array}{l}\text { Varying price } \\
\text { levels }\end{array}$ & $\begin{array}{l}\text { The greens fee varies between } \$ 50 \\
\text { and } \$ 75\end{array}$ & $\begin{array}{l}\text { Positive frame: A higher reference } \\
\text { price is mentioned first }(\$ 75) \\
\text { Negative frame: A lower reference } \\
\text { price is mentioned first }(\$ 50)\end{array}$ \\
\hline $\begin{array}{l}\text { Two-for-one } \\
\text { coupon } \\
\text { programme }\end{array}$ & $\begin{array}{l}\text { Restrictions of the use of two-for-one } \\
\text { coupons between peak periods } \\
\text { (Saturday or Sunday mornings) and } \\
\text { non-peak period (Mondays through } \\
\text { Fridays and on Saturday and Sunday } \\
\text { afternoons) }\end{array}$ & $\begin{array}{l}\text { Positive frame: 'On Mondays through } \\
\text { Fridays and on Saturday and Sunday } \\
\text { afternoons' } \\
\text { Negative frame: 'At any time except } \\
\text { on Saturday or Sunday mornings' }\end{array}$ \\
\hline $\begin{array}{l}\text { Time-of-booking } \\
\text { pricing }\end{array}$ & $\begin{array}{l}\text { A } \$ 30 \text { difference between two } \\
\text { different time spans of advance } \\
\text { booking }\end{array}$ & $\begin{array}{l}\text { Discount for early booking: } \$ 90 \text { for } 14 \\
\text { days advance booking versus } \$ 120 \text { for } \\
4 \text { days } \\
\text { Discount for late booking: } \$ 120 \text { for } 14 \\
\text { days advance booking versus } \$ 90 \text { for } \\
4 \text { days }\end{array}$ \\
\hline $\begin{array}{l}\text { Reservation fee/ } \\
\text { no-show fee }\end{array}$ & $\$ 20$ reservation fee $/ \$ 20$ no-show fee & $\begin{array}{l}\text { Positive frame: Reservation fee is } \\
\text { charged at point of reservation; the } \\
\text { fee is waived/credited if the } \\
\text { reservation is honoured } \\
\text { Negative frame: A no-show fee is } \\
\text { charged when the reservation is not } \\
\text { honoured }\end{array}$ \\
\hline $\begin{array}{l}\text { Tee time interval } \\
\text { pricing }\end{array}$ & $\begin{array}{l}\text { The tee time is increased from every } \\
8 \text { or } 9 \text { minutes to every } 15 \text { minutes, } \\
\text { and the charges are increased by } 30 \%\end{array}$ & n.a. \\
\hline
\end{tabular}


The survey included six scenario-based questions and two demographic questions.

The respondents were asked to evaluate each scenario on a scale of 1 (extremely acceptable) to 7 (extremely unacceptable). Two versions of the survey were used. The questions on both versions were identical with the exception of the wording of six demand-based pricing scenarios, in order to see whether customers reacted differently based on how the price differences were framed. Specifically, two frames (surcharge and discount) were used for time-of-day pricing and varying price levels, and two-for-one coupons were framed with restrictions with positive wording (valid on) versus a wording with exclusions (not valid on). Pricing fences using advance booking were explored with either lower fees for advance booking a longer time period in advance or lower fees for a shorter time period in advance. Finally, pricing based on tee time interval was explored as this is potentially an important duration control lever. An overview of all manipulations is provided in Table 2.

The one-page survey was mailed in October 2001, and a postage-paid envelope was included. Of the 1,000 mailed questionnaires, 102 surveys were returned because of insufficient or incorrect addresses. Of the remaining surveys, 296 were returned, resulting in an effective response rate of 33.0 per cent.

\section{RESULTS}

The summary findings are presented in Table 3 and Figure 1, and detailed findings on the revenue management practices are discussed next.

\section{Pricing practices}

Four different pricing practices were evaluated: time-of-day pricing, varying price levels, two-for-one coupon programmes and time of booking.

\section{Time of day pricing}

Golf courses typically have higher demand on weekends and particularly high demand during the early morning hours on weekends. If they charge a premium for early morning weekend play, they should be able to increase revenue while maintaining customer volume. 
Table 3: Summary findings

Revenue management practice

Mean (STD)

Overall mean

(STD)

Time-of-day pricing expressed as

- surcharge

$3.93(2.27)$

- discount

$2.91^{\mathrm{a}}(1.99)$

Varying price levels

- increasing

$6.17(1.45)$

$6.16(1.46)$

$6.16(1.45)$

- decreasing

$1.96(1.58)$

$\begin{array}{ll}1.96 & (1.58) \\ 1.62^{\mathrm{a}} & (1.24)\end{array}$

$1.80(1.43)$

- without restrictions

$5.99(1.54)$

$4.22^{\mathrm{a}}(2.28)$

- discount for early booking

$3.14(2.17)$

- no-show fee

n.a.

Tee time interval pricing

Note: $1=$ 'Extremely fair', 7 = 'Extremely unfair'.

${ }^{a}$ The difference between the two framing conditions is significant at $p>0.05$, two-tailed.

Figure 1: Perceived fairness of revenue management practices

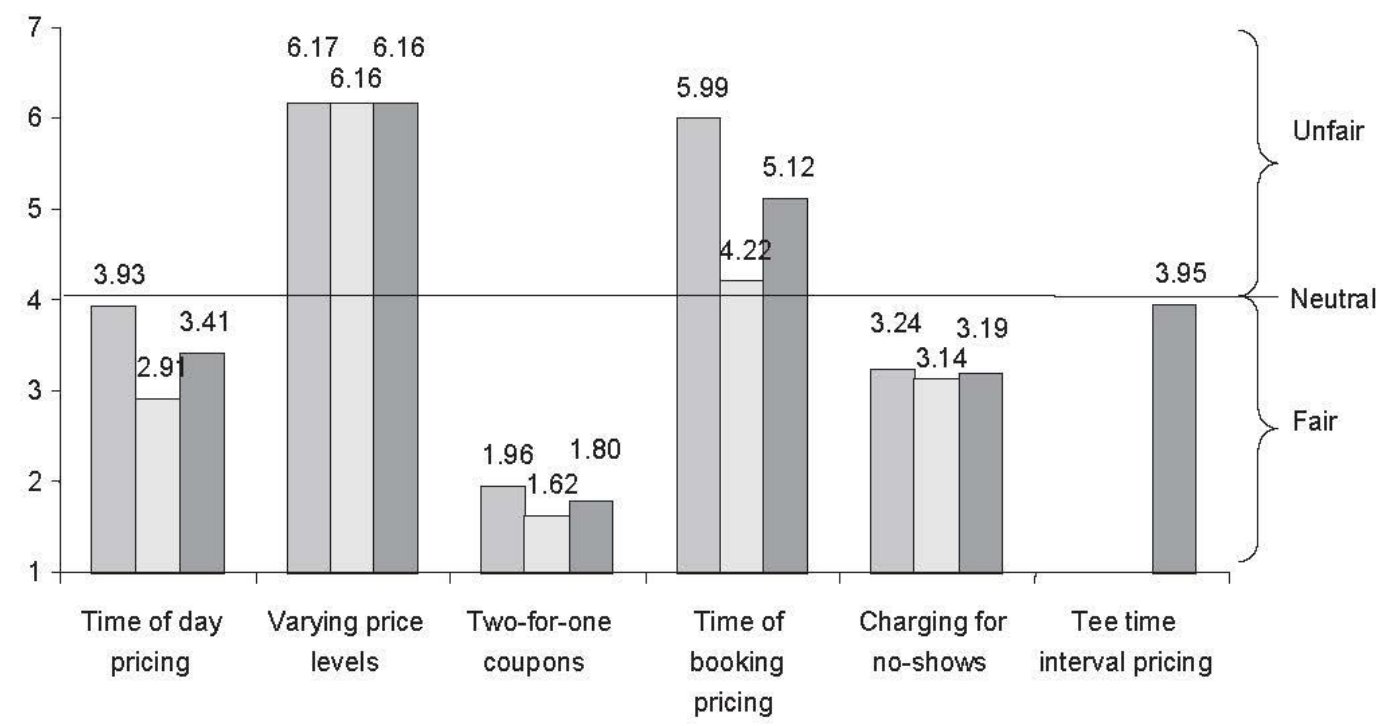

Negative $\square$ Positive $\square$ Total 
Respondents were presented with one of the following scenarios, ie either the discount scenario or the premium scenario (the latter is presented in parentheses), and were asked to evaluate its fairness:

- A golf course has two sets of weekend morning prices. If you play between 10 am and noon (before $10 \mathrm{am}$ ), the price is 20 per cent lower (higher) than if you play before (after) $10 \mathrm{am}$.

In general, customers rated time-of-day pricing as acceptable (mean=3.41). When the price was presented as a discount, customers viewed it as significantly more acceptable (mean=2.96) than when it was presented as a premium (mean $=3.92 ; \mathrm{t}=3.91 ; \mathrm{p}<0.001)$.

This implies that golf courses can charge different prices for different times of day without incurring customer wrath. Furthermore, the findings imply that a golf course should frame the price difference as a discount rather than as a premium.

Varying price levels

Many golf course professionals are concerned with how customers would react to varying price levels. This study wanted to explore varying price levels that were not easily understood by customers. This issue follows closely the varying price points generated by sophisticated revenue management systems where prices for any given day can change rapidly over time as a function of updated demand predictions for that particular time slot. The respondents were asked to evaluate the following scenarios:

- A golfer plays at the same course at the same time every Saturday morning in October. The posted rate is $\$ 60$. Some weeks your greens fee is $\$ 50(\$ 75)$ and other times your greens fee is $\$ 75(\$ 50)$.

Respondents viewed varying price levels as extremely unacceptable (mean=6.16). The reaction remained the same regardless of whether the question was phrased with a high reference price first (mean=6.16), or the low reference price first (mean=6.17). This implies that golf courses should strive to maintain consistent pricing policies. If a golfer pays a particular price for an 8:30 am tee time on Saturday one week, he/she should pay the same price the following week. 


\section{Two-for-one coupon programme}

Many golf courses use two-for-one coupon programmes to try to build business during low demand periods. The intent of this question was to assess the perceived fairness of this practice and to determine the best way in which to position such a programme. Respondents were asked to evaluate the following scenarios:

- A golf course participates in a two-for-one coupon programme. Customers can use the coupons for two-for-one rounds at any time except on Saturday or Sunday mornings (on Mondays through Fridays and on Saturday and Sunday afternoons).

Two-for-one coupon programmes were viewed as extremely acceptable (mean=1.80). Respondents viewed the practice as more acceptable when presented as not having restrictions (mean=1.62) than when it was presented as having restrictions (mean $=1.96 ; t=2.02 ; p<0.05$ ). This implies that golf courses should consider using two-for-one coupon programmes, and that these programmes should be framed positively (ie state when the coupons can be used) and not with restrictions such as not valid on weekends, etc.

\section{Time-of-booking pricing}

Some golf courses charge more for reservations that are made far in advance, and others charge more for reservations that are made very close to the date of play. The reasons for this vary and are generally related to market dynamics and the type of customers served. The intent of this question was to determine how customers view time-of-booking prices and whether they prefer premiums for early reservations or for late reservations. Respondents were asked to evaluate the following scenarios:

- You step up on the fourth tee and a member of the group you were paired with mentions that for '\$90, this course is a great value!' You and your partner paid \$120. After a brief discussion, you discover that the other twosome booked 4 (14) days in advance, while you booked 14 (4) days in advance. 
Overall, time-of-booking pricing was considered moderately unacceptable (mean $=5.12$ ). When a lower price was offered to customers who booked later, the practice was viewed as unacceptable ( $\mathrm{mean}=$ 5.99). Conversely, customers viewed the practice as marginally acceptable, if the lower greens fee was offered to customers who booked earlier rather than later (mean $=4.22 ; t=7.53 ; p<0.001$ ).

This finding implies that golf courses should approach time-of-booking pricing carefully. If they decide to pursue this practice, they should offer discounts to customers who book early and charge higher prices to customers who book near the time of play.

\section{Duration-control practices}

Reservation fee/no-show fee

Many golf courses face a serious no-show problem (Delgado-Muerza, 2000). Golf courses can overbook and/or charge either a reservation fee or a no-show fee. Even though some golf courses require a credit card guarantee for the entire greens fees for all reservations, they often have difficulty in collecting the no-show revenue from the credit card companies. Restaurants have experimented with the idea of a reservation or no-show fee and have met with great success. The intent of these questions was to determine how golfers viewed reservations and no-show fees. Respondents were presented with the following scenarios:

- Reservation fee:

A golf course has a $\$ 20$ reservation fee. If you honour your reservation, the fee is waived, but if you do not honour your reservation, you are charged the reservation fee.

- No-show fee:

A golf course charges a $\$ 20$ no-show fee per person. If you honour your reservation, you are not charged the fee, but if you fail to show up, you are charged the no-show fee.

Respondents considered a reservation fee to be acceptable (mean=3.14). This implies that a golf course should consider using a reservation fee in lieu of trying to collect the full amount of the greens fee from customers, or in lieu of not charging anything at all. The size of the reservation fee seems large enough 
to cause customers to be more responsible for cancelling their reservation but not large enough to create customer dissatisfaction.

Similarly, no-show fees were viewed as acceptable (mean=3.24). This implies that golf courses can impose no-show fees for customers who do not honour their reservation and still be perceived as behaving fairly. In addition, it does not seem to matter if the fee is framed as a reservation fee or as a no-show fee (mean=3.19, $t=0.57, p=0.57)$.

Tee time interval pricing

Many golfers complain about crowded golf courses, and some golfers prefer a longer tee time interval between parties. A longer tee time interval means that the golf course cannot serve as many customers, and unless an increased greens fee was charged, the golf course would lose revenue. The intent of this question was to determine how customers viewed an increased greens fee for a longer tee time interval. The respondents were asked to evaluate the following scenario:

- Most golf courses schedule tee times every 8 or 9 minutes. One golf course schedules tee times every 15 minutes, but charges 30 per cent more than other courses.

This practice was considered to be acceptable (mean=3.95). This implies that if a golf course offers a longer tee time interval than its competition, it can charge a premium without upsetting customers. Capacity implications and contribution need to be considered, however. The time points and pricing used in the present study are not revenue/minute neutral, as the fee increase does not fully compensate for the capacity reduction caused by the longer tee time. Should the golf course run most of the time at full capacity, the price increase would have to be higher.

\section{Demographic questions}

Respondents were asked to indicate their frequency of play and their geographic location. The intent of both questions was to determine whether the frequency of play or the geographic location was related to the perceived fairness of the seven different scenarios. One-way and two-way ANOVAs were run to explore potential main and interaction effects with our independent variables. Frequency of play was 
insignificant $(p>0.10)$, while geographic location was insignificant $(p>0.10)$ for all but time of booking $(p<0.05)$ and the no show fee $(p<0.10)$.

In general, the geographic location did not matter, but respondents living in the Southwestern USA were significantly more accepting (mean=4.60) of time-of-booking pricing than respondents living in the Midwestern USA (mean=5.52). This finding has face validity, as the general thought of the golf company is that the golfers in the Midwest and Southwest are quite different. The Southwestern golfers usually have access to year-round play, have quite a few more choices and are considered to be more sophisticated customers, and have quite a few more choices, while Midwestern golfers are generally limited to about six months of golfing per year. Finally, none of the interaction effects reached significance $(p>0.10)$.

In summary, the findings on the demographic background suggest that the findings are reasonably robust and generalisable, at least across the geographic locations and golfing frequency categories examined in this study.

\section{MANAGERIAL IMPLICATIONS AND FURTHER RESEARCH}

In general, customers view the golf revenue management practices studied as acceptable. The survey results indicate that golfers consider time-of-day pricing to be acceptable, particularly if framed as a discount. Two-for-one coupon programmes were considered very acceptable. Time-of-booking pricing was considered as moderately unacceptable, especially when a discount was given to customers who booked shortly before the day of the tee-off. Respondents viewed varying price levels as extremely unacceptable. Reservation and no-show fees were considered acceptable and golf courses should consider using them as a method for reducing no-show rates. Finally, charging a premium for an increased tee time interval was viewed as acceptable.

These findings provide golf course operators with broad acceptance levels, but do not guarantee that all customers may willingly accept demand-based pricing practices. Therefore, when developing demand based pricing using fences, golf course operators must make sure that the rate fences are easy to explain and administer, and that customers can understand the reasoning behind them. This will make it easier for the front-line employees to pacify unhappy customers and recover the service if necessary. Also, the positioning of revenue management internally to staff and externally to customers should be as a win-win situation. It needs to be emphasised that the pricing does allow patrons to selfsegment and by having tight fences, patrons who see high value in a good tee time are much more likely 
to get the capacity and service they value (Wirtz et al., 2001). This way, increasing profitability via revenue management does not have to come at the expense of customer satisfaction and loyalty.

Apart from framing of price fences, other marketing tools can be adopted to make revenue management more acceptable for the golfers. Price bundling and categorizing of the service according to some minor differing characteristics can help to manage customer conflicts arising from discriminatory pricing (Wirtz et al., 2001). Price bundling allows the golf course to offer various price tiers, thus making it harder for golfers to compare prices. This will then reduce the likelihood of perceived unfairness. Likewise, rate fences that are clearly presented to golfers that are transparent, logical and perceptible can increase total consumer satisfaction.

This study represents some of the first research on customer reaction to golf revenue management practices. The sample was restricted to USA customers of high-end daily greens-fee courses, so results may not be generalisable to other levels of courses and/or countries. Future research could replicate the rate fences studied in this paper for different levels of public courses in both the USA and other countries. Other rate fences, such as length of play, age or free cart usage could be explored in future work.

While this research was restricted to daily greens-fee courses, it could also be extended to private clubs. For example, private clubs could offer different types of memberships (ie full access, afternoons only, weekdays only) in an attempt to increase revenue.

Also, no-shows represent a major problem for many golf courses, and although some courses required credit card guarantees, they have had great difficulty in successfully collecting when customers do not honour their reservations. Additional research on methods golf courses could use to better manage and reduce no-shows would be quite useful.

In addition to the main effects studies in this paper, future work could explore potential moderating variables that might qualify the main effects found here. For example, income, level of education and familiarity with the various fences, perhaps from other industries, might affect the acceptance of revenue management practices. Also, the current study did not consider the psychological processes involved in reactions to the price fences, such as affective reactions to gains and losses in specific purchase or usage situations (Linville and Fischer, 1991). Similarly, the perceived motives and reputation of the golf course were not looked into in the current study.

From a practitioner perspective, this research could be extended to include capacity utilisation strategies issues beyond revenue management, such as customer development, bundling, and differentiation might be explored (See eg Ng et al., 1999) Finally, research into implementation of golf 
revenue management practices, such as training of reservation agents and facility staff, integration with other information technology systems and effective customer communication would be a fruitful and useful field of enquiry.

\section{SUMMARY}

In conclusion, it was found that golfers generally accepted most of the revenue management practices studied. This has considerable implications for both researchers and golf course operators as revenue management has the potential to increase golf course profitability while maintaining customer satisfaction.

\section{ACKNOWLEDGMENTS}

The authors gratefully acknowledge the excellent assistance provided by our research student Chua Hsiao Wei throughout this project. Furthermore, we should like to acknowledge the support and feedback of Troon Golf.

\section{REFERENCES}

Bennett, D. J. (1984) 'Discount fare market research 1981-83', 63rd Annual Meeting of the Transportation Research Board, 2, January.

Campbell, M. C. (1999a) " "Why did you do that?" the important role of inferred motive in perceptions of price fairness', Journal of Product and Brand Management, 8, 2, 145-152.

Campbell, M. C. (1999b) 'Perceptions of price unfairness: antecedents and consequences', Journal of Marketing Research, 36, 2, 187-199.

Carroll, W. J. and Grimes, R. C. (1995) 'Evolutionary change in product management: experiences in the car rental industry', Interfaces, 25, 5, 84-104.

Delgado-Muerza, A. (2000) 'Golf revenue management: an application to the Robert Trent Jones Golf Course at Cornell University', unpublished monograph, Cornell University School of Hotel Administration, Ithaca, NY.

Dolan, R. J. and Simon, H. (1996) Power Pricing, The Free Press, New York.

Hanks, R. B., Noland, R. P. and Cross, R. G. (1992) 'Discounting in the hotel industry, a new approach', Cornell Hotel and Restaurant Administration Quarterly, 33, 3, 40-45.

Kahneman, D. and Tversky, A. (1979) 'Prospect theory: an analysis of decision under risk', Econometrica, 47, 2, 263-291.

Kahneman, D., Knetsch, J. L. and Thaler, R. H. (1986a) 'Fairness as a constraint on profit seeking: entitlements in the market', The American Economic Review, 76, 728-741. 
Kahneman, D., Knetsch, J. L. and Thaler, R. H. (1986b) 'Fairness and the assumptions of economics', Journal of Business, 59, S285-S300.

Kaufmann, P. J., Ortmeyer, G. and Smith, N. C. (1991) 'Fairness in consumer pricing', Journal of Consumer Policy, 14, 117-140.

Kimes, S. E. (1994) 'Perceived fairness of yield management', Cornell Hotel and Restaurant Administration Quarterly, 35, 1, 22-29.

Kimes, S. E. (2000) 'Revenue management on the links: applying yield management to the golf-course industry', Cornell Hotel and Restaurant Administration Quarterly, 41, 1, 120-127.

Kimes, S. E. and Chase, R. B. (1998) 'The strategic levers of yield management', Journal of Service Research, 1, 2, 156-166.

Kimes, S. E. and Noone, B. M. (2002) 'Perceived fairness of yield management: an update', Cornell Hotel and Restaurant Administration Quarterly, 43, 1, 28-29.

Kimes S. E. and Schruben, L. W. (2002) 'Golf course revenue management: a study of tee time intervals', Journal of Revenue and Pricing Management, 1, 2, 111-120.

Kimes, S. E. and Wirtz, J. (2002) 'Perceived fairness of demand-based pricing for restaurants', Cornell Hotel and Restaurant Administration Quarterly, 44, 1, 1-7.

Linville, P. W. and Fischer, G. W. (1991) 'Preferences for separating and combining events', Journal of Personality and Social Psychology, 60, January, 5-23. National Golf Foundation (2002) 'Frequently asked questions', http://www.ngf.org/faq\#2

Ng, I. C. L., Wirtz, J. and Lee, K. S. (1999) 'The strategic role of unused service capacity', International Journal of Service Industry Management, 10, 2, 211-238.

Smith, B. A., Leimkuhler, J. F. and Darrow, R. M. (1992) 'Yield management at American Airlines', Interfaces, 2, 1, 8-31.

Thaler, R. F. (1985) 'Mental accounting and consumer choice', Marketing Science, 4, 3, 199-214.

Urbany, J. E., Madden, T. J. and Dickson, P. R. (1989) 'All's not fair in pricing: an initial look at the dual entitlement principle', Marketing Letters, 1, 1, 17-25.

Wirtz, J., J. Ho, P. T. and Patterson, P. G. (2001) 'Yield management: resolving potential customer and employee conflicts', The NUS Business School Research Paper Series, No. 2001-026 (Mkt), National University of Singapore. 